\title{
Rynek jako czynnik ograniczający wolność słowa
}

$\mathrm{J}$ edną z najistotniejszych zmian w zasadach funkcjonowania państwa, zainicjowanych obradami Okragłego Stołu, była likwidacja instytucji cenzury i urzeczywistnienie powszechnego prawa dostępu do informacji. Likwidacja Głównego Urzędu Kontroli Pracy, Publikacji i Widowisk doprowadziła do dynamicznego rozwoju rynku prasowego, radiowego i telewizyjnego ${ }^{1}$. Gazeta, program radiowy i telewizyjny stały się produktami, których sprzedaż podlegała takim samym prawom, jak sprzedaż każdego innego towaru. Na rynku pojawiło się wiele nowych tytułów prasowych (nowe produkty), które zostały zaakceptowane przez czytelnika (klienta) lub zostały przez niego odrzucone i tym samym upadły (musiały zniknąć z rynku). Wydawcy gazet i czasopism bardzo często odwołują się do stwierdzenia, że czytelnicy codziennie (lub co tydzień) głosują na nich, a kartką wyborczą jest moneta, za którą kupują gazetę, urną zaś kiosk w którym dokonują zakupu.

Jednak wolny rynek, którego powstanie w mediach było konsekwencją urzeczywistnienia wolności słowa, może ograniczać tę jedną z podstawowych wolności obywatelskich. Przy czym wolność słowa należy rozumieć szeroko. Nie tylko jako możliwość swobodnego głoszenia swoich poglądów, ale także jako możliwość wyboru różnych tytułów prasowych oraz dostępność ich na rynku. Wolność słowa to także wyraźne oddzielenie w gazecie i czasopiśmie materiałów dziennikarskich od materiałów reklamowych.

Analizę zależności między wolnością słowa a zasadami wolnego ryn$\mathrm{ku}$ proponuję rozpatrzyć w trzech aspektach.

Po pierwsze, recesja gospodarcza zmniejsza ofertę rynkową i ogranicza dostęp do gazet i czasopism.

Po drugie, koncentracja kapitału w mediach i dumping cenowy powodują ograniczenie liczby wydawanych tytułów, a tym samym wolumen opinii i informacji docierających do czytelnika.

1 Zob. W. Adamczyk, Media masowe w procesie budowania demokracji $w$ Polsce (1989-1995), UAM, Poznań 1999, s. 15-56. 
Po trzecie wreszcie, uzależnienie wydawców od reklamodawców, powoduje, iż „ten kto płaci dyktuje warunki, czyli selekcjonuje informacje i opinie oraz przedstawia siebie w dobrym świetle". Często można spotkać się z opinią, że „wolność słowa, to wolność wydawcy, a nie dziennikarza”, a głoszą ją przede wszystkim ci pierwsi.

\section{Spadek czytelnictwa prasy}

Według danych Związku Kontroli Dystrybucji Prasy, styczeń 2004 roku był drugim miesiącem z rzędu, w którym „Fakt” był najlepiej sprzedającym się dziennikiem. W styczniu średnia sprzedaż „Faktu” była jeszcze wyższa (o 1,7\%) od rekordowej sprzedaży z grudnia 2003 roku wyniosła 545388 egzemplarzy. Spośród pozostałych dzienników ogólnopolskich wszystkie tytuły, z wyjątkiem „Pulsu Biznesu” i „Gazety Giełdy Parkiet", miały w styczniu 2004 roku niższą sprzedaż niż w styczniu i grudniu ubiegłego roku, jak również niższą od średniej za cały 2003 rok. „Gazeta Wyborcza” miała średnią sprzedaż na poziomie 398599 egzemplarzy (o 8,7\% mniej niż w styczniu 2003 roku). Trzecią pozycję zajmuje „Super Express” - 256436 egzemplarzy (spadek o 8,6\%). Kolejne miejsca: „Rzeczpospolita” - 181168 egzemplarzy (spadek o 1\%), „Trybuna” - 25792 egzemplarzy (spadek o 13,7\%), „Puls Biznesu” 22820 egzemplarzy (wzrost o 3,6\%), „Parkiet Gazeta Giełdy”- 10939 egzemplarzy (wzrost o 34,3\%). Najnowszy dziennik, reaktywowane „Życie”, które weszło na rynek 15 stycznia 2004 r., nie jest zarejestrowane w ZKDP.

Niemal wszystkie najważniejsze tygodniki opinii miały w 2003 roku niższą średnią sprzedaż niż rok wcześniej - pokazują dane Związku Kontroli Dystrybucji Prasy za cały ubiegły rok. Liderem w tym segmencie rynku jest „Newsweek Polska”, którego średnia sprzedaż w 2003 roku wyniosła 216244 egzemplarzy i była niższa o 14,2\% niż rok wcześniej. Średnia sprzedaż „Polityki” wyniosła 206301 egzemplarzy (spadek o 7,9\%), „Wprost” - 184150 egzemplarzy (spadek o 2,1\%), „Przeglądu” - 48049 egzemplarzy (spadek o 6,1\%). Przed ten ostatni tytuł wywindował się w rankingu „Przekrój”, notując wzrost aż o 84,7\% w porównaniu z 2002 rokiem - jego średnia sprzedaż wyniosła 86696 egzemplarzy. To wynik zmian, jakie przeprowadzono w piśmie na początku ubiegłego roku, a odnowiony tygodnik wspierano kampanią reklamową. Wydawnictwu Edipresse Polska udało się reaktywować „Przekrój”. 
Jeżeli chodzi o inne tygodniki społeczne, to wzrost sprzedaży o 7,8\%, do 29161 egzemplarzy, zanotował tygodnik przedruków z prasy zagranicznej „Forum”. Wzrosła też sprzedaż tygodnika „Angora”, z przedrukami z polskiej prasy - o 1,1\%, do 254808 egzemplarzy. Natomiast aż o 20,4\%, do 171235 egzemplarzy, spadła średnia sprzedaż „Nie”.

W grudniu 2003 średnia sprzedaż „Newsweek Polska” wyniosła 217929 egzemplarzy, „Wprost” - 209216 egzemplarzy, „Polityki” 208623 egzemplarzy, „Przekroju” - 104272 egzemplarzy, „Przeglądu” 41942 egzemplarzy, „Forum” - 27852 egzemplarzy, „Angory” - 266342 egzemplarzy, „Nie” - 151291 egzemplarzy. Warto jednak zauważyć, że wchodząc w 2001 roku na polski rynek „Newsweek Polska” osiagał sprzedaż w wysokości ponad 400 tys. egzemplarzy (wysokość sprzedaży pierwszych numerów jest zawsze zawyżona, gdyż reklama i renomowany tytuł zawsze przyciaga czytelników). Zdecydowanie wyższa sprzedaż notowały pod koniec ubiegłego stulecia ówcześni liderzy rynku: „Wprost” (ponad 300 tys. egzemplarzy) i „Polityka” (280-290 tys. egzemplarzy).

Zdecydowany spadek czytelnictwa stał się także udziałem prasy regionalnej. Tylko jeden z dziesięciu największych dzienników regionalnych sprzedawał się w styczniu tego roku lepiej niż w styczniu 2003 - wynika z danych Związku Kontroli Dystrybucji Prasy. Choć dziennikom regionalnym nie udało się powtórzyć wyników sprzedaży sprzed roku, to jednak udało im się zahamować gwałtowny spadek sprzedaży, jaki dotknął je szczególnie pod koniec ubiegłego roku. Dla większości styczeń 2004 był lepszy od grudnia 2003. Z danych ZKDP za pierwszy miesiąc 2004 r. wynika, że trójka najlepiej sprzedających się dzienników to: „Gazeta Pomorska” - ze średnią sprzedażą 97016 egzemplarzy (spadek o 6,2\% w porównaniu ze styczniem ubiegłego roku), „Dziennik Zachodni” - 76764 egzemplarzy (spadek o 17,4\%), „Dziennik Bałtycki” - 65768 egzemplarzy (spadek o 10,7\%). Dziesiątkę największych dzienników regionalnych uzupełniają: „Express Ilustrowany” - 60841 egzemplarzy (spadek o 8,6\%), „Dziennik Polski” - 58144 egzemplarzy (spadek o 15,9\%), „Dziennik Łódzki” 54456 egzemplarzy (spadek o 6,6\%), „Gazeta Lubuska” - 51649 egzemplarzy (jedyny wzrost o 1,6\%), „Trybuna Śląska” - 45465 egzemplarzy (spadek o 19,1\%), ,Słowo Polskie - Gazeta Wrocławska” - 45450 egzemplarzy (dziennik powstał 1 grudnia 2003 roku z połączenia trzech tytułów dolnośląskich), „Gazeta Poznańska” - 38487 egzemplarzy (spadek o $14,5 \%$ ).

W tym miejscu warto przyjrzeć się jeszcze jednemu zestawieniu. Do końca ubiegłego roku w większości województw prasa lokalna domino- 
wała nad prasą centralną. Jedynie w jednym województwie - Mazowieckim, „Gazeta Wyborcza” była najlepiej sprzedającym się dziennikiem. W pięciu województwach (Dolnośląskim, Lubuskim, Opolskim, Pomorskim, Śląskim) była wśród dwóch najlepiej sprzedających się dzienników. W tym roku sytuacja zmieniła się diametralnie. „Fakt” zdominował nie tylko rynek ogólnopolski, ale także rynki regionalne. Jest on najlepiej sprzedającym się dziennikiem w trzech województwach (Wielkopolskie, Lubelskie i Śląskie), zaś w dziesięciu jest w pierwszej dwójce. Jedynie w województwach: Kujawsko-Pomorskim, Łódzkim, Podlaskim, Podkarpackim nie ma tego tytułu w gronie rynkowych liderów ${ }^{2}$.

Można przyjąć założenie, że dzięki niskiej cenie egzemplarza i atrakcyjnej formie całotygodniowego programu telewizyjnego, „Fakt” pokonał konkurencję. Można także dyskutować nad jakością i formą podawania informacji. Jeżeli tak liczna grupa czytelników kupuje ten tytuł, to znaczy że spełnia on ich oczekiwania. Jest jeszcze jeden aspekt tego zagadnienia. Okazuje się, że „Fakt” ujawnił istnienie sporej grupy czytelników, która dotychczas nie znajdowała na rynku swojego tytułu. Bezpodstawne - przynajmniej w pierwszych miesiącach, okazały się spekulacje, iż nowy tytuł zdobędzie czytelników odbierając ich dotychczasowym liderom prasowego rynku.

\section{Koncentracja kapitału czynnikiem ograniczający wielość opinii}

Najbardziej spektakularnym dowodem koncentracji kapitału w mediach w ostatnich miesiącach 2004 roku był zakup przez jedno wydawnictwo trzech tytułów prasy regionalnej i połączenie ich w jeden tytuł. Polskapress najpierw kupiła, a następnie połączyła trzy tytułu wychodzące we Wrocławiu, a mianowicie: „Słowo Polskie”, „Gazetę Wrocławską” i „Wieczór Wrocławia” w jedną gazetę - „Słowo Polskie - Gazeta Wrocławska"3. Wydawca wielokrotnie podkreślał, że główną przesłanką podjęcia takiej decyzji był czynnik ekonomiczny. Recesja spowodowała drastyczne ograniczenia wpływów z reklam, a tym samym na lokalnym rynku ,nie było miejsca" dla trzech dzienników. Można było przewidywać, że skupienie kilku tytułów w rękach jednego wydawcy doprowadzi do ograniczenia ofert dla czytelników. Trudno bowiem wyobrazić sobie sytuację,

2 Zob. Lokalne zamieszanie, „Gazeta Wyborcza” z dn. 15.02.2004 r.

3 Zob. Wrocławskie trzy w jednym, ,Gazeta Wyborcza” z dn. 29-30.11.2003 r. 
w której ten sam wydawca wydaje trzy takie same, albo bardzo podobne tytuły prasowe adresowane do tego samego odbiorcy. Takie rozwiązanie nie ma ekonomicznego uzasadnienia.

Przykład wrocławski nie jest pierwszym, ani jedynym tego typu przypadkiem w naszym kraju. Jednak groźba powstania monopolu informacyjnego spowodowała, że transakcja zakupu tytułów i ich koncentracja we Wrocławiu stała się przedmiotem zainteresowania Urzędu Ochrony Konkurencji i Konsumenta. Przedmiotem zainteresowania UOKiK była także transakcja w Poznaniu. Tu jednak ten sam wydawca zachowuje, jak dotychczas, rozdzielność obu posiadanych tytułów. W obu przypadkach Urząd uznał transakcje za nieważne i nakazał powrót do stanu wyjściowego. Strony odwołały się od tej decyzji i sprawa jest w toku. Ze zjawiskiem koncentracji na lokalnym rynku mieliśmy także do czynienia w Gdańsku i Łodzi, jednak wówczas UOKiK nie zareagowat ${ }^{4}$.

Koncentracja kapitału w mediach (ale nie tylko) prowadzi do możliwości sprzedaży poniżej kosztów wytwarzania. Celem takiego postępowania jest wyeliminowanie konkurencji (szczególnie gdy jest ona słabsza ekonomicznie i nie może lub nie zamierza walczyć tymi samymi metodami). Działania takie są prawnie zakazane, ale niezmiernie trudno jest udowodnić, że wydawca sprzedaje określony tytuł prasowy poniżej kosztów produkcji. Ustawa o ochronie konkurencji i konsumentów zakazuje nadużywania pozycji dominującej „na rynku właściwym” przez przedsiębiorcę (np. wydawcę) za pomocą narzucania nieuczciwych cen (art. 8). Z kolei w ustawie o zwalczaniu nieuczciwej konkurencji, można znaleźć zapis mówiący o tym, że utrudnianie innym przedsiębiorcom (np. wydawcom) dostępu do rynku, poprzez sprzedaż wyrobów (np. gazet i czasopism) poniżej kosztów ich wytworzenia - w celu wyeliminowania z rynku innych przedsiębiorców - jest przejawem nieuczciwej konkurencji.

Na obie ustawy powołała się spółka Media Express (wydawca „Super Expressu") w swoim wniosku, skierowanym do Urzędu Ochrony Konkurencji i Konsumentów, w sprawie rozpoczęci postępowania antymonopolowego przeciwko wydawcy dziennika „Fakt”. . Wydawca „Super Expressu” zarzucał Axel Springerowi, że nadużywa dominującej pozycji na rynku tabloidów, poprzez stosowanie antykonkurencyjnych cen. Zdaniem wnioskodawcy, sprzedaż egzemplarza gazety za 1 zł - zdaniem wnioskodawcy

4 Zob. A. Nalewajk, Dominacja, „Press” 2004, nr 3, s. 36-40.

5 Zob. „Fakt” drapieżnik?, „Gazeta Wyborcza” z dn. 19.02.2004 r. 
- oznacza sprzedawanie produktu poniżej kosztów jego wytworzenia. W chwili pisania artykułu, sprawa była w toku postępowania. Dotychczasowa praktyka pokazuje, że UOKiK nie traktował sprzedaży poniżej kosztów wytwarzania za przejaw nieuczciwej konkurencji. Podstawą wszczęcia postępowania i skierowania sprawy do sądu będzie więc udowodnienie, że działania wydawcy dziennika „Fakt”, zagrażają interesom konsumentów lub je naruszają. Można założyć, że w interesie klienta jest nieograniczony dostęp do informacji, a więc działania wydawcy mogą ten interes naruszać. Naruszają tym samym szeroko rozumianą zasadę wolności słowa.

\section{Uzależnienie od reklamodawcy czynnikiem ograniczającym wolność słowa}

O ile dwa pierwsze aspekty relacji między zasadami wolnego rynku a wolnością słowa są wymierne, o tyle trzeci aspekt tego problemu nie posiada już takiej właściwości. Przypadki uzależniania wydawcy od reklamodawcy, wpływania na zawartość i kształt materiału dziennikarskiego są dość liczne, lecz bardzo często mówi się o nich nieoficjalnie. Jeżeli nawet sprawa wyjdzie na jaw, to obie strony usilnie zaprzeczają iż taka sytuacja zaistniała.

Trudno jest w tej sytuacji odwoływać się do konkretnych przykładów, trudno generalizować i wyciągać wnioski. Na niektóre drastyczne przypadki zwracają uwagę czytelnicy. Ich uwagę przykuwa np. sytuacja, w której w czasopiśmie wywiad z prezesem firmy X sąsiaduje z reklamą firmy X. Można domniemywać, że firma X wykupuje reklamę, ale „w prezencie" od wydawcy otrzymuje możliwość zaprezentowania czytelnikowi poglądów swojego prezesa. Nie trzeba dodawać, iż w takiej rozmowie między dziennikarzem a prezesem nie pada żadne trudne lub kontrowersyjne pytanie. Prezes kreuje się supermenedżera, a firma osiąga rewelacyjne wyniki.

Podobnie krytyczne uwagi wywołują różnego rodzaju rankingi i raporty, których sponsorami są zainteresowane firmy. Czy nie dochodzi do naruszenia wolności słowa $\mathrm{w}$ sytuacji, w której np. sponsorem raportu o rynku paliwowym jest koncern petrochemiczny, a „patronem” rankingu najlepszych ofert bankowych duży bank, który na dodatek okazał się w tym rankingu najlepszy. Można spotkać się z rankingami, których zasady i kryteria konstruowane są nie przez redakcję, lecz przez „ekspertów” 
wywodzących się lub współpracujących z firmami zainteresowanymi wynikami rankingu.

Często, autoryzacja wypowiedzi osób występujących w materiale dziennikarskim sprowadza się do autoryzacji całego artykułu. W tej sytuacji, to nie dziennikarz, lecz „bohater” materiału prasowego jest jego autorem. Poprawia cały tekst, a w wywiadzie próbuje także zmieniać pytania dziennikarza.

Można zaryzykować twierdzenie, że wpływ reklamodawców na treść materiałów dziennikarskich jest uzależniona od siły ekonomicznej wydawnictwa i tytułu prasowego. Im jest ona większa tym wpływy są mniejsze. Wszyscy wydawcy i większość tytułów prasowych jest uzależniona od wpływów z reklamy.

W okresie recesji ekonomicznej tytuły prasowe przyciagają reklamodawców nie tylko obniżając ceny reklam czy stosując specjalne rabaty. Oferują „coś” więcej, często jest to milcząca zgodna na ingerencję w zawartość materiałów prasowych. Cała nadzieja w tym, iż pojawiających się symptomach wychodzenia z recesji. Można więc żywić nadzieję, że wolny rynek wyeliminuje wszelkie patologie i rynkowe ograniczenia wolności słowa.

\section{Summary}

The author attempts to consider the relationship between freedom of speech and the principles of the free market in three aspects. Firstly, economic recession reduces the market offer and restricts access to newspapers and magazines. Secondly, the concentration of capital in the media and dropping of prices results in a limited number of titles circulating, thus restricting the amount of opinions and news releases reaching the readers. Thirdly, the dependence of editors on the advertisers makes ,the one who pays dictate the terms, i.e. select the information and opinion and present himself in good light”. The opinion is frequently encountered that ,freedom of speech is the freedom of the editor as opposed to that of a journalist", which is mainly voiced by the former. 